\title{
S ビルにおける室内温熱環境調査と執務者の受容性に関する考察 INVESTIGATION OF INDOOR THERMAL ENVIRONMENT AND CONSIDERATION ON THERMAL ENVIRONMENTAL ACCEPTABILITY AT OFFICE S
}

\author{
鵜飼真成*, 高橋満博**, 村上宏次 ${ }^{* *}$, 雨宮沙 耶 $^{* * *}$, 野部 達夫**** \\ Masanari UKAI, Mitsuhiro TAKAHASHI, Köi MURAKAMI, \\ Saya AMEMIYA and Tatsuo NOBE
}

\begin{abstract}
This study aims to evaluate the thermal comfort of an indoor environment in office from physical quantity and psychological state. Moreover, this study aims to assess the thermal conditions of an indoor environment deemed unacceptable by workers that it is impossibility to evaluate from conventional method. For this purpose, the acceptability voting device "Ostracon" was developed, which can record the physical environment when workers express a complaint. Workers can push a button on Ostracon to vote when they feel that the thermal environment is unacceptable. In this study, Ostracon was used to measure whether 25 workers felt that the thermal environment was acceptable in the office $\mathrm{S}$ during the summer. The results showed that the questionnaire about satisfaction with the room environment, the many of respondents said they were "comfort" overall. The result showed a very high level of satisfaction. Regarding the survey of Ostracon, subjects expressed that the environment was unacceptable even when the temperature and humidity were within an acceptable range. Therefore, the authors consider that thermal environmental acceptability is not determined simply by temperature and humidity. However, it was observed that the workers' complaints were often expressed moments after returning from tasks performed outside the office, suggesting that their complaints were influenced by factors other than the office environment, such as changes in metabolic rate and the individual's thermal history.
\end{abstract}

Keywords : Measurement investigation, Thermal comfort, Thermal acceptability, Ostracon, Workplace, Radiant air-conditioning system 実測調査, 熱的快適性, 温熱受容性, オストラコン, ワークプレイス, 放射空調

1. はじめに

\section{1 研究背景}

快適な環境とは何か。建築は古来より各地域で気候・風土に即し た形態や機能を備えてきたが, 温熱環境の制御という面では脆弱で あった。しかしながら, 冷凍空調技術が一般化される以前の建築で は, 暖かい日光や心地よい風等、自然エネルギーを積極的に取り込 む知恵が溢れている。我が国の寝殿造では, 夏になると襖や障子を 開け放つことで涼を取り，冬は土壁で囲まれた塗籠に移動すること で寒さをしのぐ工夫がされていた 1)。19 世紀の中頃になると, 欧米 の諸国では大規模法人の出現によるオフィスビルの建設が始まり, 英国リバプールのオリエル・チャムバー社（1864 年）の室内には暖 炉が備えられていた 2)。オフィスビル成立時の温熱環境調整手法は, 換気・通風とストーブ程度であったが，20世紀初頭には米国のラー キンビル (1906 年) に代表されるように, オフィスには空調設備が 導入され, 空は嵌め殺しへと変様した。
空調が建築に装備されて以来，室内温熱環境は空間的に均一かつ 時間的に一定であることを目標としてきたが，技術の進歩は熱的快 適性に関する問題を複雑にした。室内の熱的快適性を空の開閉や建 具により調整していた時分には，居住者は自分の環境を自分で制御 することが可能であったが，空調システムの出現により，大規模才 フィス等の室内温熱環境の制御は設備管理者に託される事例が多く なった。ここで問題となるのが熱的快適性の判断基準であるが, 空 調設備の発展とともに温熱指標も進展を続けている。

今日，ISO 7730 に採用されている PMVや，ASHRAE 55 による SET*は，人体と周囲の環境による熱収支を理論的に追及した後に， 定常状態の環境試験室を用いた被験者実験から得られた温冷感申告 值と結び付けて評価しており, 温熱 6 要素の入力により得られる結 果は，性別，年齢，人種，気候，空間の用途等に関わらず適用でき るとしている ${ }^{3)}$ 。PMV や SET*といった温熱指標は，空調設計の数 值目標を明確化し，温熱環境制御の基準として多大な貢献をしたこ

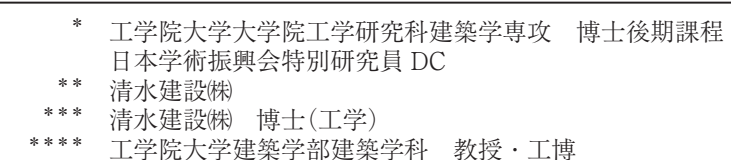

工学院大学大学院工学研究科建築学専攻 博士後期課程 清水建設侏

**** 工学院大学建築学部建築学科 教授. 工博

Grad. Stud., Dept. of Architecture, Faculty of Engineering, Kogakuin University JSPS Research Fellow

Shimizu Corporation

Shimizu Corporation, Dr.Eng.

Prof., Dept. of Architecture, Faculty of Architecture, Kogakuin University, Dr.Eng. 
とは紛れもない事実であろう。しかしながら, 環境試験室の物理環 境や被験者の着衣と行動を厳密に管理した実験室実験の結果を, 一 般的な温熱指標として扱うことには疑問が呈されている4)。 Humphreys and Nicol5) は「人は快適な環境を獲得するための自発 的な適応能力を備えている」という概念から, 現実の環境では居住 者が着衣の調整をはじめとする適応行動をとるため, PMV の予測 結果と実際の快適温度には差が生じると述べている。中野ら $\left.{ }^{6}\right)$ は, 非定常環境下である半屋外環境における環境適応を考慮した熱的快 適性の概念図を提案している。また, Humphereys \ $^{7}$ は環境適応を理 解するための, 実際の執務環境下における実測調查の必要性を指摘 している。

現実の環境における実証的研究ではオフィス空間などのワークプ レイスにおける知的生産性の評価や, 執務者の行動特性に関する調 查等多くの報告 8-15)があるが，オフィスのような目的空間において 執務者の熱的快適性に関する情報収集は容易ではない。アンケート 調査では執務者の一人ひとりから直接情報を収集できるというメリ ットがあるが，あくまでも大まかな定性的印象評価であり，想像以 上に空間を動き回りながら複雑な仕事をしているオフィスワーカー の非定常状態における瞬間的な不満は顕在化されにくい。また, ア ンケート調査では「問われて敢えて答えるならば」と云うバイアス が潜む恐れがあり, 回答の背後にある状況の推測を難しくしている。

\section{2 研究目的}

工学的に快適とは「不快でないりという消極的な定義であるため, 不快発生時の状況を解き明かすことは, 一般的な快適を理解するこ とと関連すると思われる。本研究の目的は, 夏期オフィスにおける 室内温熱環境の快適性を物理的側面や心理的側面から評価するのと 同時に，実際のオフィスで働く執務者が，室内の温熱環境に対して 非受容と感じる瞬間を捉えることであり, 従来の物理環境調査とア ンケート調查からでは抽出できない室内温熱環境に対する不満を見 出すことである。

\section{2. 実測調査方法}

\section{1 調査建物概要}

表 1 に実測対象オフィスの概要を示す。本建物は 2012 年 5 月に 竣工し， 7 月から運用を開始した。空調方式は放射空調とデシカン トによる潜熱・顕熱分離空調が導入されている。図 1 に空調システ ムの概要を示す。ペリメータチルドビームはフィン形状をしており, 夏期は冷水を供給して自然対流を促進させ，ペリメータ冷房負荷の 処理を行っている。冬期は温水を供給して放射天井パネルとして機 能し, 暖房負荷の処理を行っている。インテリアゾーンはタスク\& アンビエント方式を採用している。インテリアは年間を通して冷房 負荷があるため, アンビエント空調はインテリア放射天井パネルに 冷水を供給し, 人体, 照明, $\mathrm{OA}$ 機器等による内部発熱を処理する。 インテリア放射天井パネルは $3.2 \mathrm{~m}$ モジュールで 10 枚の放射パネ ルと 2 枚の点検口パネルで構成されているため, 敷設率は約 $70 \%$ と なる。タスク空調はデシカント空調機で温湿度処理された外気が, 机下に設置されたパーソナル床吹出口（表 2）から供給される。パ ーソナル床吹出口は在席者が好みに合わせて開閉し気流を調整する ことができる。
表 1 建物概要

\begin{tabular}{|c|c|}
\hline 所在地 & 東京都中央区 \\
\hline 敷地面積 & 約 $3,000 \mathrm{~m}^{2}$ \\
\hline 延床面積 & 約 $51,800 \mathrm{~m}^{2}$ \\
\hline 構造 & $\begin{array}{l}\text { 鉄筋コンクリート（一部鉄骨造） } \\
\text { 免震構造 }\end{array}$ \\
\hline 階数 & 地下3階, 地上 22 階, 塔屋1階 \\
\hline 主用途 & 事務所 \\
\hline CASBEE & Sランク（BEE 9.7） \\
\hline LEED & $\mathrm{NC}$ (新築) ゴールド \\
\hline 設計期間 & 2005 年7月～2009年 4 月 \\
\hline 施工期間 & 2009年4月～2012年5月 \\
\hline
\end{tabular}
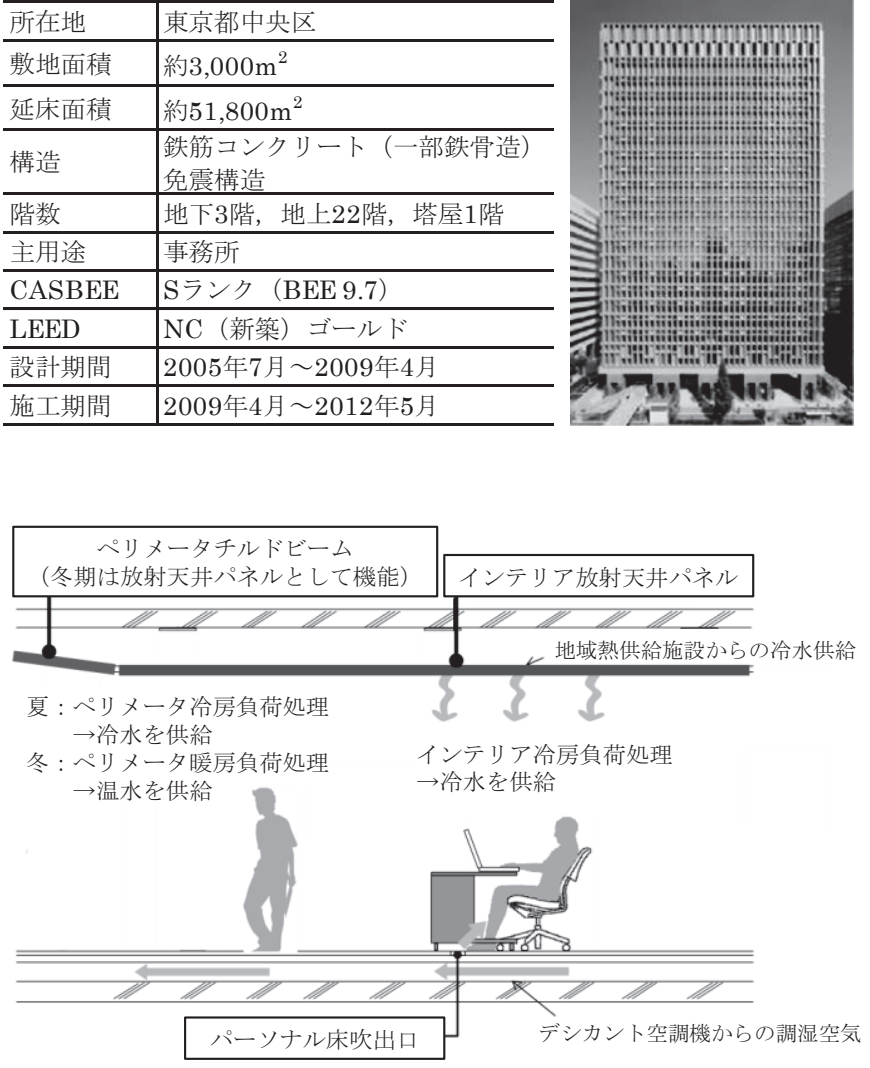

図 1 空調システム概要

表 2 パーソナル床吹出ロ

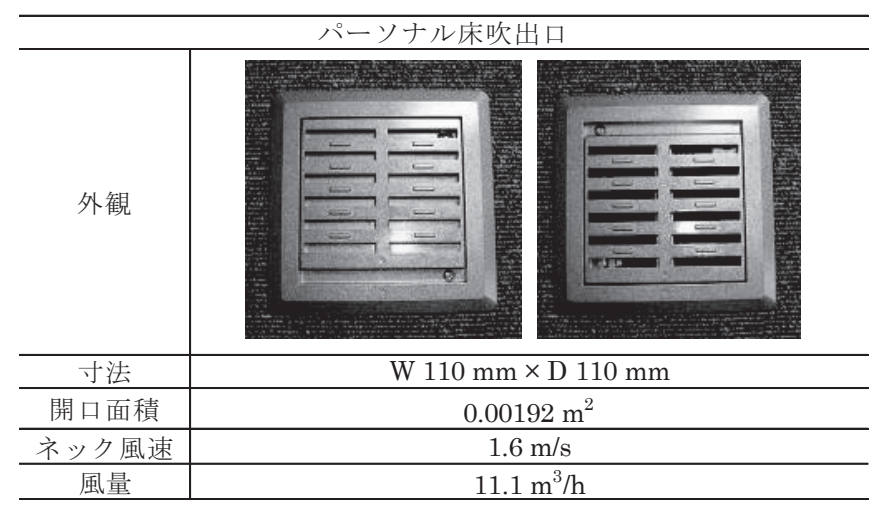

表 3 室内環境測定項目

\begin{tabular}{|c|c|c|c|}
\hline 測定位置 & \multicolumn{2}{|l|}{ 測定項目 } & 計測間隔 \\
\hline & \multicolumn{2}{|l|}{ 上下温度分布 } & $10 \mathrm{~min}$ \\
\hline & \multicolumn{2}{|l|}{ 相対湿度 } & $10 \mathrm{~min}$ \\
\hline & \multicolumn{2}{|l|}{ グローブ温度 } & $10 \mathrm{~min}$ \\
\hline & \multicolumn{2}{|l|}{ 気流性状 } & - \\
\hline \multirow{4}{*}{$\cup$} & \multirow{3}{*}{ 受容度（オストラコンを使用） } & 空気温度 & $4 \min$ \\
\hline & & 相対湿度 & $4 \mathrm{~min}$ \\
\hline & & パルスロガー & $2 \mathrm{~min}$ \\
\hline & \multicolumn{2}{|c|}{ 着席状況（着座センサーを使用） } & $1 \mathrm{~min}$ \\
\hline
\end{tabular}




\section{2 室内温熱環境の長期連続測定}

温熱環境の計測は 2013 年 7 月 23 日から 2013 年 8 月 30 日にか けて, $18 \mathrm{~F}$ の北西側にて行った。室内環境測定項目の概要を表 $3 に$, 対象オフィスの平面図および室内環境測定箇所を図 2 に示す。ペリ メータ 2 点, インテリア 4 点の計 6 点にて, 上下温度分布 (床表面, 床上 $100 \mathrm{~mm}, 600 \mathrm{~mm}, 1100 \mathrm{~mm}, 1700 \mathrm{~mm}, 2200 \mathrm{~mm}, 2700 \mathrm{~mm}$, 天井表面), グローブ温度, 相対湿度 (それぞれ床上 $1100 \mathrm{~mm}$ )を 10 分間隔で測定した。また, 調查期間中の設定温湿度はペリメータが $26^{\circ} \mathrm{C} / 45 \%$ ，インテリアが $27^{\circ} \mathrm{C} / 45 \%$ あった。

\section{3 気流性状調査}

3 次元超音波風速計を用いた気流性状の詳細な測定は, 2013 年 8 月 24 日に実施した。測定箇所は図 2 に示寸ように, インテリアと ペリメータの各 1 点とした。

\section{4 執務者アンケート調査}

対象オフィスにおける執務者の快適性，ならびに放射空調とパー ソナル床吹出口についての印象評価が可能なアンケート調査を実施 した。表 4 にアンケートに関する申告項目と尺度を示す。アンケー 卜調查期間は, 温熱環境調查実施日に合わせ， 2013 年 7 月 23 日か ら 2013 年 8 月 30 日とし, 対象者には調査期間中の任意のタイミン グで 1 回のみ, 夏期の室内温熱環境に対する総合的な印象を回答す るようにお願いした。また, アンケートの総配布数は 200 部であり, 回収数は 179 部であった。

\section{5 執務者の受容度調査}

\section{5 .1 非受容申告装置オストラコン}

表 5 に示す装置は, 非受容申告の発生状況を詳細に補足するため に, 著者らが考案したデバイスである。本装置の呼称として用いた オストラコンとは, 古代ギリシャで追放者を選出する際に投票用紙 のように使われた陶片のことを指すが，制作した装置も人知れず不 満を簡単に表明する手段として，陶片と類似の機能を果たす。

非受容申告装置オストラコン（以下オストラコンと記す。）は机上 に置いて, 執務者が暑すぎて或いは寒寸ぎて我慢ならない場合にボ タンを押してもらうことで, 不満発生時の時刻がオストラコン内部 のパルスロガーに記録される仕組みとなっている。また, オストラ コンには温湿度ロガーを取り付けているため, 非受容申告発生時の 机上における空気温度と相対湿度を確認することが可能である。そ の特徵として, 執務者の自発的な申告を容易に記録可能であること から, アンケート調查等とは異なるデータが得られるものと期待を 込めて開発した。図 2 にオストラコンを配布した執務者の座席位置 を示寸。受容度調查は 2013 年 7 月 29 日から 2013 年 8 月 9 日にか けて, 執務者 25 名（男性 19 名・女性 4 名・不明 2 名）を詨象に実 施した。

\subsection{2 着席検知装置}

本調査では執務者の着席状況を把握するために, 表 6 に示す座布 団型の着席検知装置を併用した調查を行った。着席検知装置は, 座 布団内に仕込まれた温度ロガーの值の変化を読み取ることで, 執務 者の離着席状況を判断できる仕組みである。
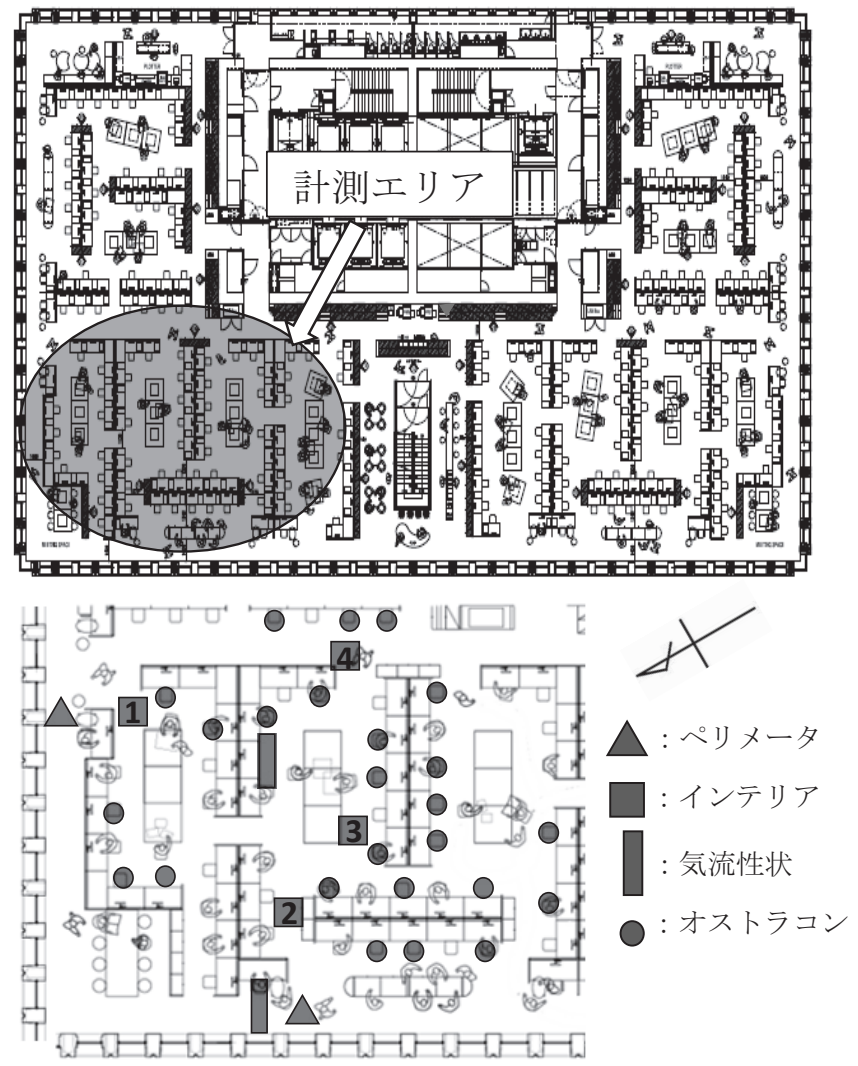

図 2 対象建物平面図および室内環境測定箇所

表 4 アンケートの申告項目と尺度

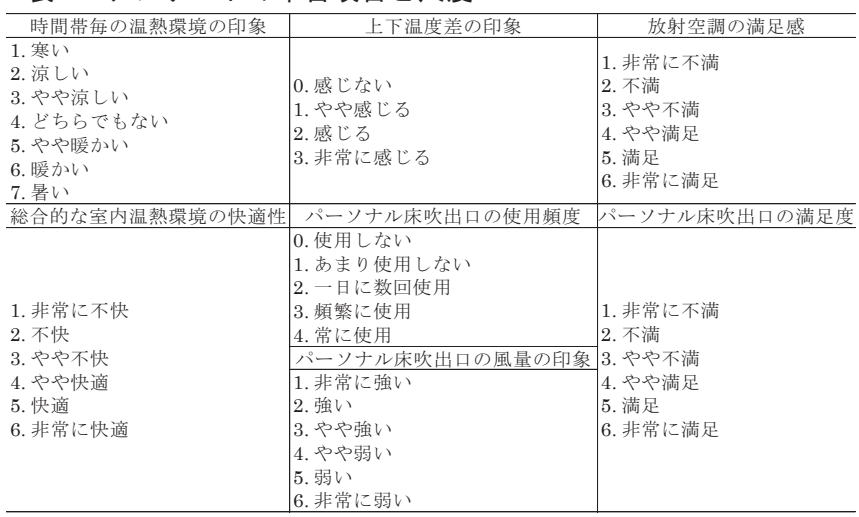

表 5 非受容申告装置オストラコン

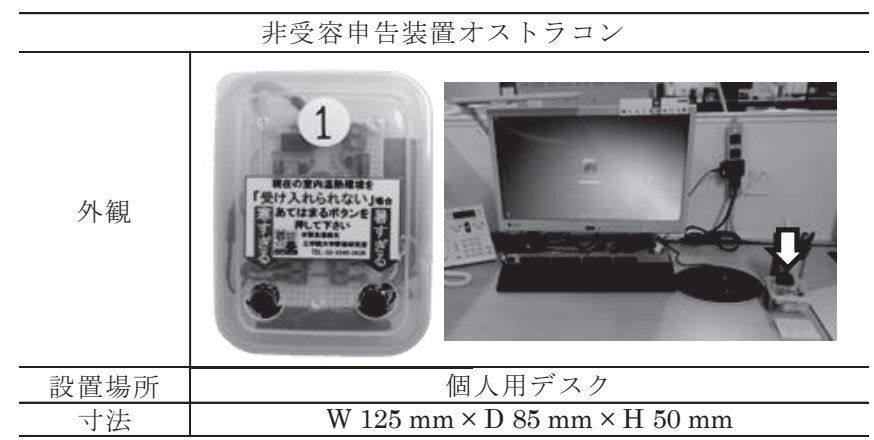




\section{3. 実測結果}

\section{1 長期連続測定}

\section{1 .1 温熱環境の経時変化}

図 3 に代表日 8 月 9 日（実測期間中の最高外気温日）における外 気温度 (気象庁アメダスの観測データ), ペリメータ 2 点, インテリ ア 4 点の各計測点 $(\mathrm{FL}+1100)$ における平均空気温度および, イン テリアの平均 $\mathrm{MRT}$ と平均相対湿度の経時変化を示す。 MRT は式 （1）に実測值を代入して求めたが，風速に関しては空間全体に静穏な 気流環境が形成されていると仮定して $0.1 \mathrm{~m} / \mathrm{s}$ を使用した。朝 7 時 から夕方 18 時にかけての空気温度は，インテリア，ペリメータと もに概称 $27^{\circ} \mathrm{C}$ に保たれ，相対湿度は $45 \%$ 付近を推移していること から, 執務時間中の温湿度は設定值付近で非常に安定していること を確認した。

$$
t_{r}=t_{g}+2.37 \sqrt{v}\left(t_{g}-t_{a}\right) \quad\left[{ }^{\circ} \mathrm{C}\right]
$$

$$
\text { ここに, }
$$

$$
\begin{array}{ll}
t_{r}: & \mathrm{MRT} \quad\left[{ }^{\circ} \mathrm{C}\right] \\
t_{g}: & \text { グローブ温度 }\left[{ }^{\circ} \mathrm{C}\right] \\
t_{a}: & \text { 空気温度 }\left[{ }^{\circ} \mathrm{C}\right] \\
v: & \text { 風速 }[\mathrm{m} / \mathrm{s}]
\end{array}
$$

\section{1 .2 上下温度分布}

図 4 に代表日 8 月 9 日におけるペリメータ,インテリアそれぞれ の上下温度分布を時間帯ごとに示す。放射天井パネルには冷水が流 れているため, 表面温度は約 $23^{\circ} \mathrm{C}$ と室温に比べて低くなっている が，空気温度の上下分布は非常に小さいことを確認した。さらに， 時間の変化に対しても, 空気温度は $27^{\circ} \mathrm{C}$ 付近で大きな変化はない ため, 放射空調の特徵である均一な温熱環境が形成されていると思 われる。

\subsection{3 平均放射温度}

図 5 に通常業務日執務時間内（8:00 から 18:00）の，インテリア とペリメータの各計測点 FL+1100 における空気温度と平均放射温 度の関係をバブルチャートで示す。バブルの大きさは度数を表すが、 空気温度と比較して平均放射温度が低い結果となり, 放射天井パネ ルの泠却効果を確認した。

\section{2 気流性状調査}

図 6 に 3 次元超音波風速計を用いた気流性状調査結果を示す。ぺ リメータゾーンでは天井の屈曲部付近において右廻りの下降気流を 確認した。ペリメータゾーンにおける空気循環の存在には，ペリメ 一タチルドビームが外皮負荷を処理し，放射と対流を組み合わせた ハイブリッド型の空調システムが実現していると考えられる。また, インテリアゾーンにおいても平均 $0.07 \mathrm{~m} / \mathrm{s}$ の気流が確認され, 放射 天井パネルにより冷却された空気の自然対流を確認した。

\section{3 執務者アンケート調査}

\subsection{1 執務者基本属性}

表 7 にアンケートの回答者に対する基本属性を示す。アンケート 回答者の性別は大多数が男性であり，主な職種は技術職であった。 また，着衣量に関してはアンケートに記入された体の各部位に対応 する衣服の単品ク口值を合算し, 式(2)もしくは式(3)の回帰式に代入 して推定した ${ }^{17)}$ 。各執務者の着衣量は, 男性平均で $0.56 \mathrm{clo}$, 女性平 均で 0.48 clo であった。
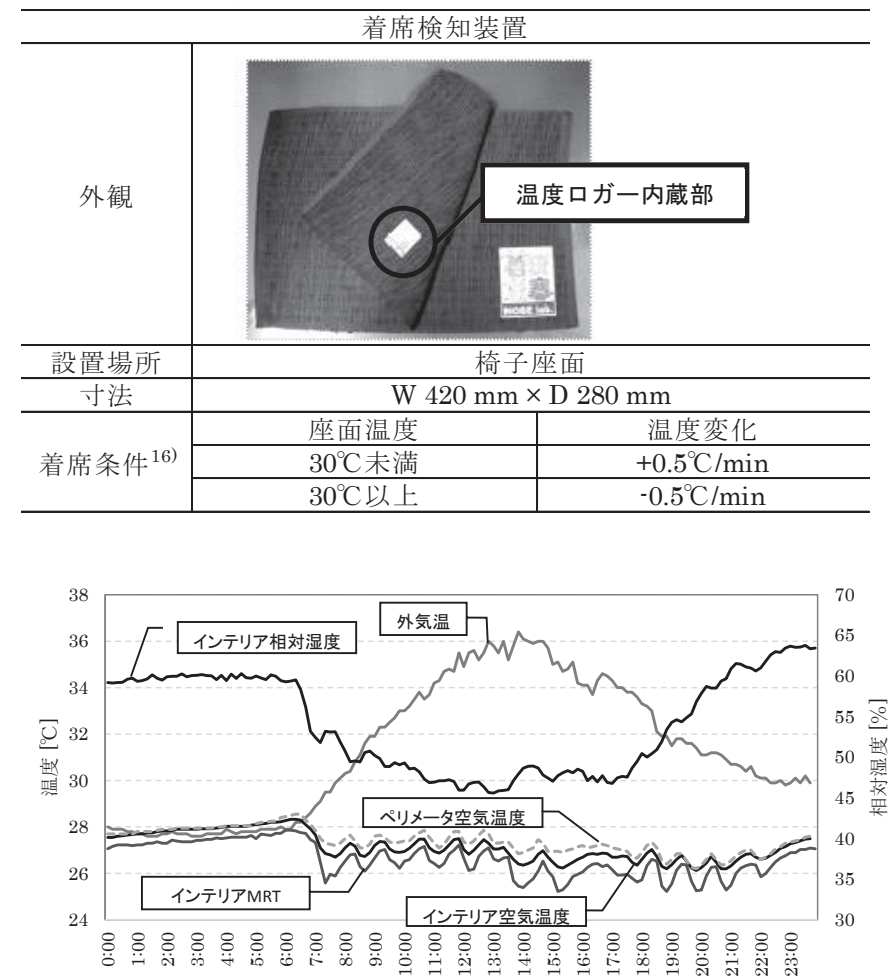

図 3 室内温熱環境の経時変化
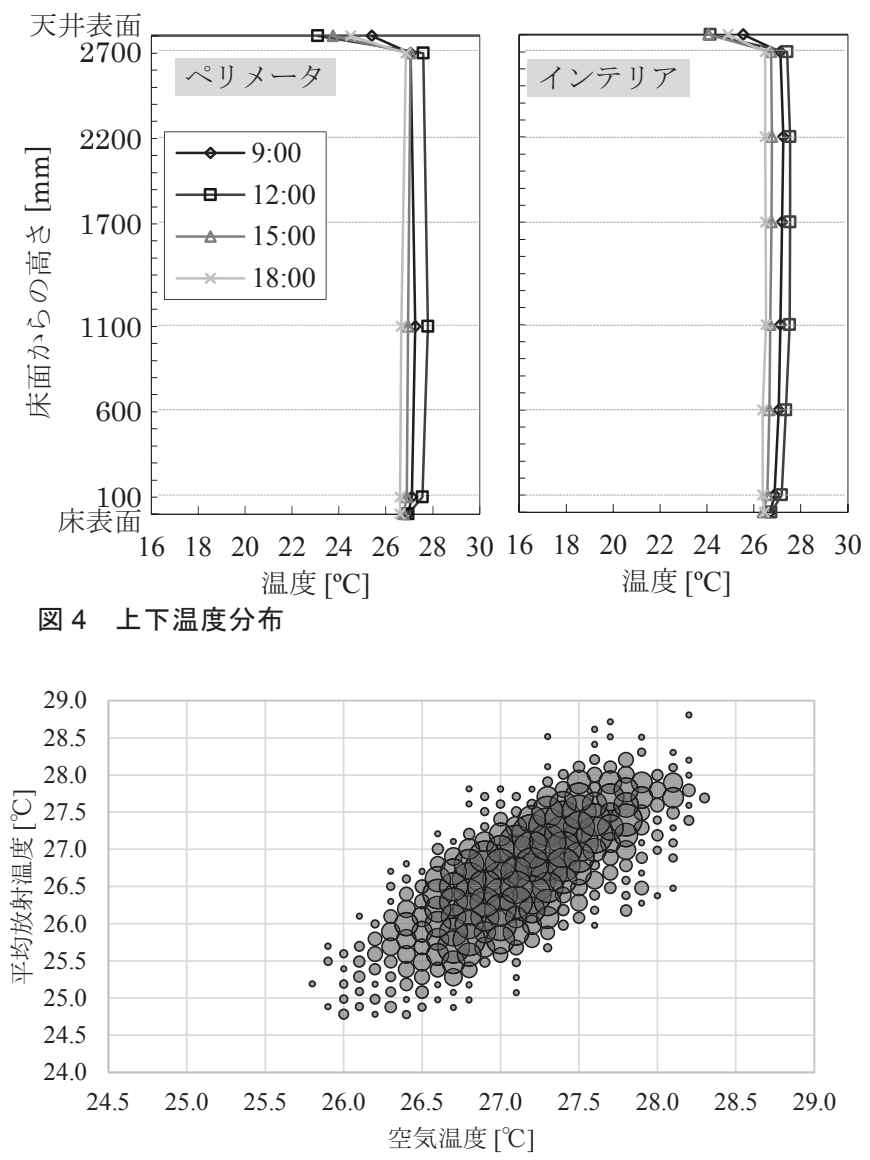

図 5 空気温度と平均放射温度の関係 
男性衣服の場合

$I_{\text {clo }}=0.708 \sum I_{\text {clo }, i}+0.052 \quad[$ clo $]$

女性衣服の場合

$I_{\text {clo }}=0.828 \sum I_{\text {clo }, i}+0.013 \quad$ [clo $]$ ここに,

$$
\begin{array}{lll}
I_{c l o}: & \text { 着衣全体のクロ值 } & {[\mathrm{clo}]} \\
I_{c l o, i}: & \text { 衣服 } i \text { の単品クロ值 } & {[\mathrm{clo}]}
\end{array}
$$

\subsection{2 室内温熱環境の快適性評価}

図 7 と図 8 に室内温熱環境の印象を示す。すべての時間帯におい て約 8 割の回答が「やや暖かい」から「やや涼しい」の熱的中立側 の領域の範囲であり, 室内上下温度差に関する質問では, 男性, 女 性ともに「感じない」の回答が約 8 割を占めた。また, 図 9 に示す 放射天井パネルの直接的な気流がないことに対する満足感と, 図 10 に示寸総合的な温熱環境の快適性は, 男性, 女性それぞれ満足側, 快適側の回答が大多数であった。したがって, 本建物では放射空調 の最大の特徵である, 気流感による不快が取り除かれた, 均一かつ 一定の環境が実現できていると思われる。

\subsection{3 パーソナル床吹出ロの印象評価}

図 11 にパーソナル床吹出口の使用頻度を, 図 12 にパーソナル床 吹出口の風量に対する印象を示す。男性は 7 割以上で常に使用, 或 いは頻繁に使用している結果となり, 風量に関しては弱い側の回答 が多い結果となった。一方で, 女性は頻繁に使用, または常に使用 している執務者は 4 割程度であり, あまり使用しない, 或いは使用 しない回答が 3 割程度確認され, 風量の印象に関しては強い側の回 答が多く見られた。男性と女性で使用頻度と風量の印象が異なる要 因のひとつとして, 着衣量の差が考えられる。女性回答者は薄手の スカートか男性用のズボンと比較すると丈の短いスラックスを着用 しており，さらに靴下類はストッキングまたは，ショートソックス やフットカバーが着用されていた。一方で, 男性回答者はズボンと ハイソックスを着用しており, パーソナル床吹出口からの気流を直 接足元で受ける女性とは気流感の印象が異なると推察される。しか し, 図 13 に示寸ように, 使用頻度や風量の印象は男女で異なる結 果であっても, 7 割以上の執務者がパーソナル床吹出口に満足して いる結果となった。

\section{4 執務者の受容度調査}

\section{4 .1 外気温と非受容申告}

図 14 に調查日毎の非受容申告数と外気温度を示す。調査期間中 の非受容申告数の合計は，「暑すぎる」申告が 53 回，「寒すぎる」申 告が 10 回であり, 複数の執務者が一日の温熱環境に何らかの不満 を抱えている事実が確認された。本調査では,「暑すぎる」非受容申 告が多い結果となったが，調查期間中に最高外気温日を記録した 8 月 9 日においては「寒すぎる」申告も発生しており, 外気温と非受 容申告数の間に関係性は見られなかった。

\section{4 .2 机上の作用温度と非受容申告}

図 15 にオストラコン全 25 台が記録した, 調查期間中の執務時間 内（8:00 から 18:00）における受容度調査対象者それぞれの机上の 作用温度の時間平均值と, 単位時間当たりの非受容申告数の関係を 示す。また，オストラコンでは放射環境の測定が困難であるため, 作用温度の算出に必要な MRT は各オストラコンに最も近い長期連

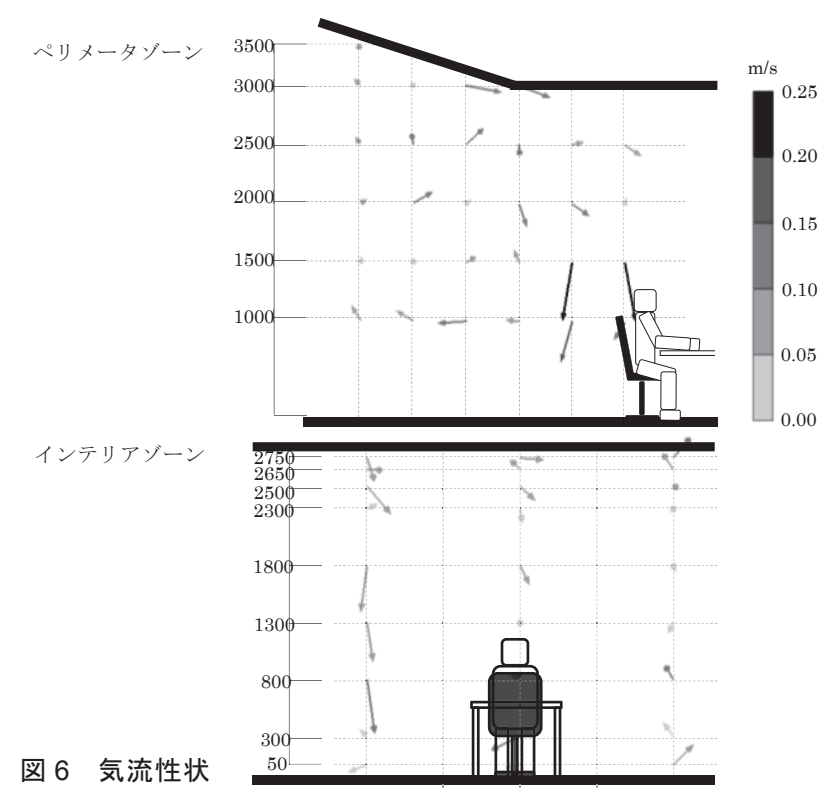

\begin{tabular}{|c|c|c|c|c|c|c|c|}
\hline \multicolumn{2}{|c|}{ 性別（人） } & \multicolumn{2}{|c|}{ 職種（人） } & \multicolumn{2}{|c|}{ 年齢（人） } & \multicolumn{2}{|c|}{ 着衣量（平均值clo, 標準偏差） } \\
\hline \multirow{2}{*}{ 男性 } & \multirow{2}{*}{158} & 事務職 & 19 & 20代 & 36 & \multirow{2}{*}{ 男性 } & \multirow{2}{*}{$0.56,0.04$} \\
\hline & & 技術職 & 159 & 30 代 & 22 & & \\
\hline \multirow{2}{*}{ 女性 } & \multirow{2}{*}{21} & 研究職 & 0 & 40代 & 64 & \multirow{2}{*}{ 女性 } & \multirow{2}{*}{$0.48,0.13$} \\
\hline & & その他 & 0 & 50 代 & 53 & & \\
\hline & & & & 60代 & 4 & & \\
\hline
\end{tabular}

表 7 基本属性

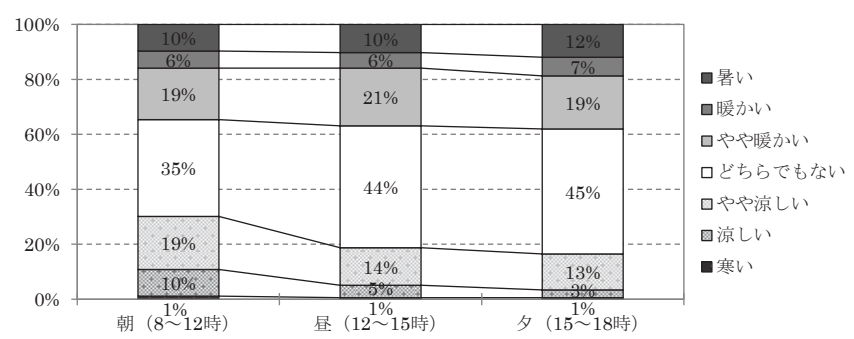

図 7 時間帯毎の温熱環境の印象

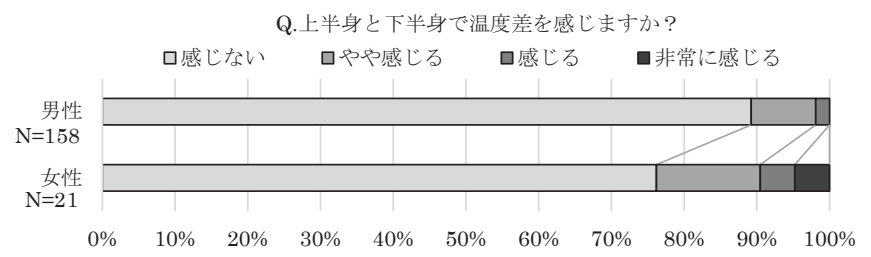

図 8 上下温度差の印象

Q.放射空調は従来のエアコンとは異なる，静穏な気流環境 が特徵でありますが, 満足していますか?

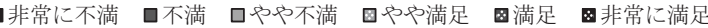

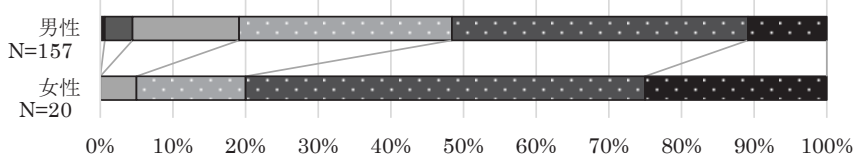

図 9 放射空調の満足感

Q.総合的な室内温熱環境の快適性はいかがですか?

口非常に不快 口不快口やや不快 圆やや快適 因快適 四常に快適

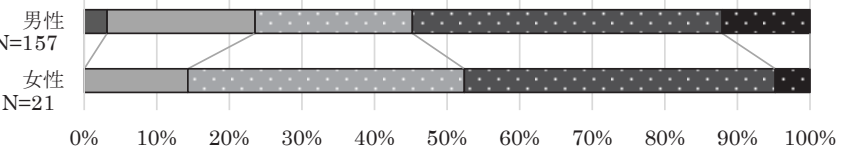

図 10 総合的な室内温熱環境の快適性 
続測定（インテリアゾーン）のグローブ温度とオストラコンが記録 した机上の空気温度を式（1）に代入して求めた。図 16 に各測定点 (インテリアゾーン) における, グローブ温度の単位時間 (10min) 当たりの変化量を代表日（8月 9 日）について示す。各測定点にお いてグローブ温度の変動が一致していたことから, 机上の作用温度 の推定に長期連続測定のグローブ温度を使用可能であると判断した。 また，単位時間当たりの非受容申告数は式(4)より求めた。

単位時間当たりの申告数 $\left[\frac{\text { 回 }}{\mathrm{h}}\right]=\frac{\text { 調查期間中の非受容申告記録数 [回 }]}{\text { 着席時間記録数 }[\mathrm{min}]} \times 60$

机上の作用温度は $26.7^{\circ} \mathrm{C}$ から $27.5^{\circ} \mathrm{C}$ であったが，特に多い「暑 すぎる」申告 0.41 回/h を行った執務者周辺の温熱環境の質は顕著 に低いわけではなく, むしろ作用温度 $26.9{ }^{\circ} \mathrm{C}$ は室内温熱環境の設 定值に近接していた。この執務者は, 30 代, 着衣量 $0.39 \mathrm{clo}$ の一般 的な女性であったが, 時間帯毎の温熱環境の印象は昼 (12 時から 15 時）が「どちらでもない」と回答していたのに対して，朝（8 時か ら 12 時）と夕方（15 時から 18 時）は「暑い」と回答していた。ま た，調查期間中におけるオストラコンの「暑すぎる」申告数に関し ても 8 時台から 11 時台に 7 回, 12 時台から 14 時台に 3 回, 15 時 台から 18 時台に 7 回と, 朝と夕方の時間帯に申告が集中していた。 特に 8 時台に関しては 6 回の「暑すぎる」申告が発生していたが, 申告時の机上の作用温度の平均值は $26.8^{\circ} \mathrm{C}$ であった。当執務者が出 社時に使用している鉄道駅から，本建物までは徒歩 10 分程度であ るが, 出社時における代謝量の変化や熱的な履歴の影響により, 朝 8 時台の「暑すぎる」申告が多く発生したのだと思われる。

\subsection{3 非受容申告時の温熱環境}

図 17 は ASHRAE Standard 55-2013 Graphic Comfort Zone Method に非受容申告時の温熱環境をプロットしたグラフである。 破線で示す領域は着衣量 0.50clo の条件における SET*の基準に沿 った熱的受容域であるため, 受容度調査対象者の中から着衣量が 0.50cloに近かった者 7 名 (0.49clo) を対象として, 非受容申告時 の温熱環境をプロットした。非受容申告 14 回の内, 11 回は熱的受 容域の申告であることから, 執務者は一般にいわれる熱的受容域に おいても非受容を発することが確認された。一方で、灰色で示した 極小プロットはオストラコンが記録した対象執務者着席時の温熱環 境であるが, 熱的受容域を外れていて着席しているにもかかわらず, 非受容を発しないときが存在することも確認した。

Q.パーソナル床吹出口の使用頻度はどの程度ですか?

ロ常に使用 ロ頻繁に使用 ロ一日に数回使用 回あまり使用しない使用しない

$\mathrm{N}=149$

女性

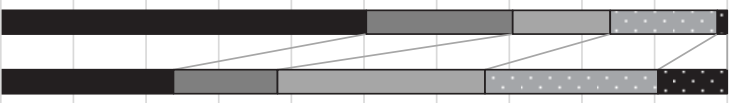

$\begin{array}{lllllllllll}0 \% & 10 \% & 20 \% & 30 \% & 40 \% & 50 \% & 60 \% & 70 \% & 80 \% & 90 \% & 100 \%\end{array}$ 図 11 パーソナル床吹出ロの使用頻度

Q.パーソナル床吹出口の風量はいかがですか?
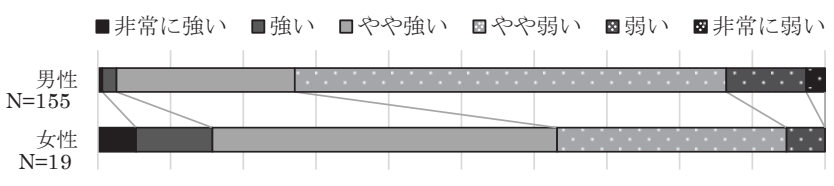

$\begin{array}{lllllllllll}0 \% & 10 \% & 20 \% & 30 \% & 40 \% & 50 \% & 60 \% & 70 \% & 80 \% & 90 \% & 100 \%\end{array}$

図 12 パーソナル床吹出ロの風量
Q.パーソナル床吹出口の満足度はどの程度ですか?

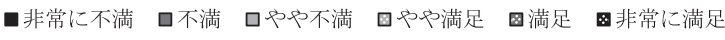

$\mathrm{N}=158$

女性
$\mathrm{N}=21$

$\begin{array}{lllllllllll}0 \% & 10 \% & 20 \% & 30 \% & 40 \% & 50 \% & 60 \% & 70 \% & 80 \% & 90 \% & 100 \%\end{array}$

図 13 パーソナル床吹出ロの満足度

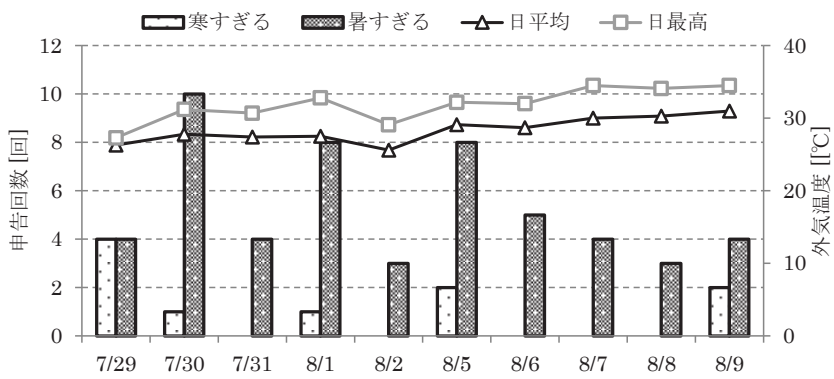

図 14 外気温と非受容申告

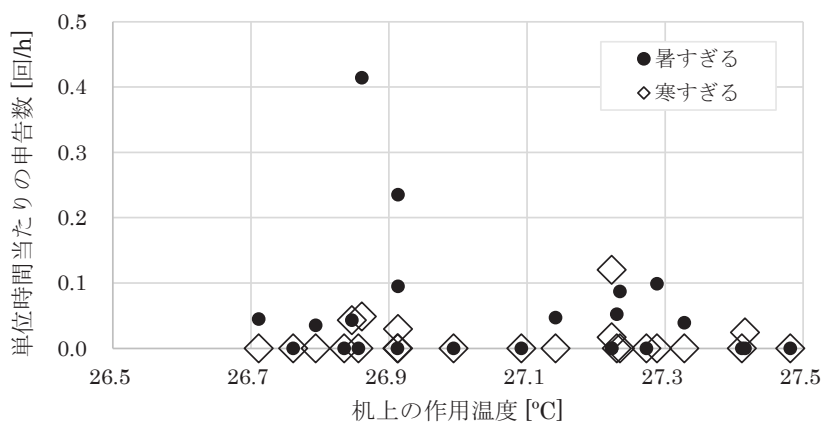

図 15 机上の作用温度と非受容申告

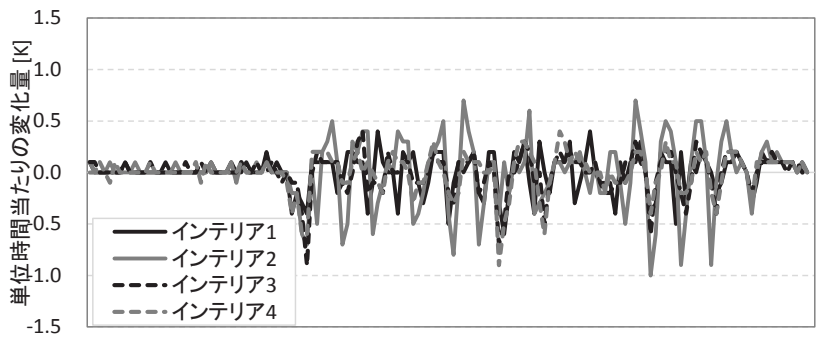

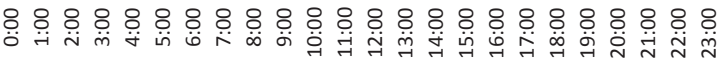

図 16 グローブ温度の単位時間（10min）当たりの変化量

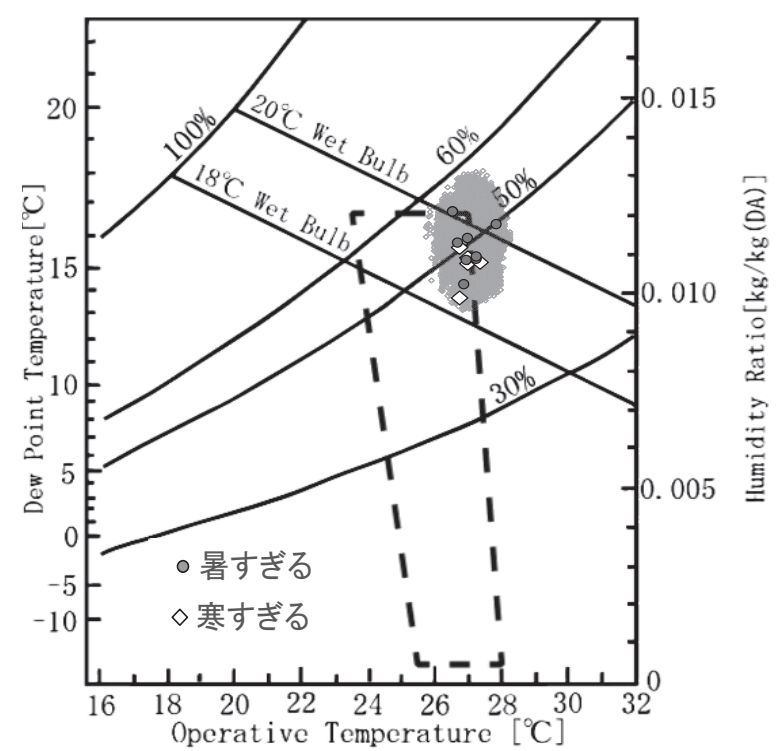

図 17 非受容申告発生時の温熱環境 


\section{1 アンケートによる印象評価と非受容申告}

図 18 にアンケート調查により得られた, 受容度調查対象者の総 合的な室内温熱環境の快適性と単位時間当たりの非受容申告数の関 係を示す。快適性の印象と非受容申告数の間には緩やかな負の相関 $(\mathrm{r}=-0.41)$ が確認され, 最も多くの非受容を発した執務者 (女性) の室内温熱環境の印象は「やや不快」であった。本実測対象の建物 は放射空調とデシカントによる潜熱顕熱分離方式が採用されている が, 一般的な空調システムによる, 吹き出し口からのドラフトやペ リメータによる不均一な温熱環境, 男女の着衣差による至適温度の 違いなどは, 非受容発生の要因となると思われる。一方で, 図 17 に 示したように，熱的受容域の内外を問わずに非受容申告が発生して いる結果は, オフィスの温熱環境を幾ら精緻にコントロールしたと ころで, 熱的不満の根本的な解消には至らないことも示唆している。

\section{2 継続着席時間と非受容申告}

図 19 に非受容申告数を継続着席時間記録数で除した值を男女別 に示す。 1 日/1 人当たりの申告数は男性 0.17 回, 女性 0.60 回と破 線で示した女性の申告数が多い結果となった。申告の内訳を継続着 席時間ごとに見てみると,「暑すぎる」申告は継続着席時間 5 分以下 に頻発し，一方で「寒すぎる」申告は長時間着席時に発生しており， この傾向は特に女性で顕著であった。図 20 はアンケート調查で執 務者に質問した「汗かきかどうか」の体質に着目した上で「暑寸ぎ る」非受容申告数を継続着席時間記録数で除した值である。着席の 直後に関しては, 特に女性で「汗かき」と回答した執務者からの「暑 すぎる」非受容申告が頻発していることを確認した。図 21 に非受 容申告数を着席時間記録数で除した值を時刻ごとに示す。暑すぎる」 申告が集中する時刻は 8 時台と夕刻であり, 朝の出社時や外回りか らの帰社時のタイミングと一致していたことから, 執務者は外部環 境から入室して自席に着いた直後に「暑すぎる」不満を持つ機会が 多いと推察される。着席直後に「暑寸ぎる」申告が集中している要 因として, 外部環境による温熱履歴の影響が考えられる。特に「汗 かき」の女性に関しては, 発汗による化粧崩れや汗染み, また臭気 の発生等を嫌うため着席直後の「暑すぎる」申告が頻発したと思わ れるが, 温熱履歴や発汗が原因となる不快の考察は, 今後さらに深 めていく必要がある。また, 長時間着席時においては女性の「寒す ぎる」申告が増加傾向にあることから, 室内温熱環境に順応した後 は, 男女の着衣差より非受容申告が多く生まれるのだと考えられる。 本建物ではパーソナル空調としてのパーソナル床吹出口が設置され ているが，その満足度は図 13 に示すように高い傾向にあった。し かし図 22 に示すように, パーソナル床吹出口に満足している執務 者においても非受容を発している結果は, 我々の想像以上に外部環 境で忙しく働き回る執務者の熱的な履歴を瞬間的に取り除くために は，パーソナル空調としては不相応な程の能力が必要であると思わ れる。したがって, オフィス空間として適当な空調システムを用い て, 執務者の温熱受容性を高めるためには, 人間の非定常性を考慮 した新たな設計手法の構築が必要であると思われる。

\section{5. まとめ}

放射空調とデシカントによる潜熱顥熱分離方式が採用されている オフィスにおける室内温熱環境の快適性を, 物理的側面と心理的側

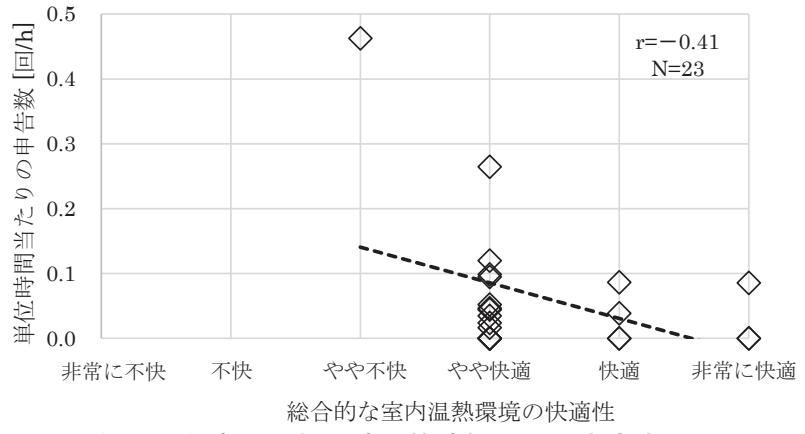

図 18 総合的な室内温熱環境の快適性と非受容申告

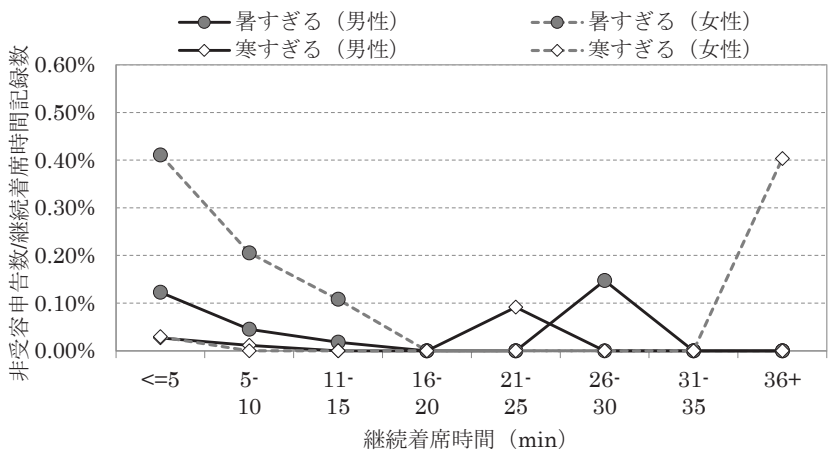

図 19 継続着席時間ごとの非受容発生率

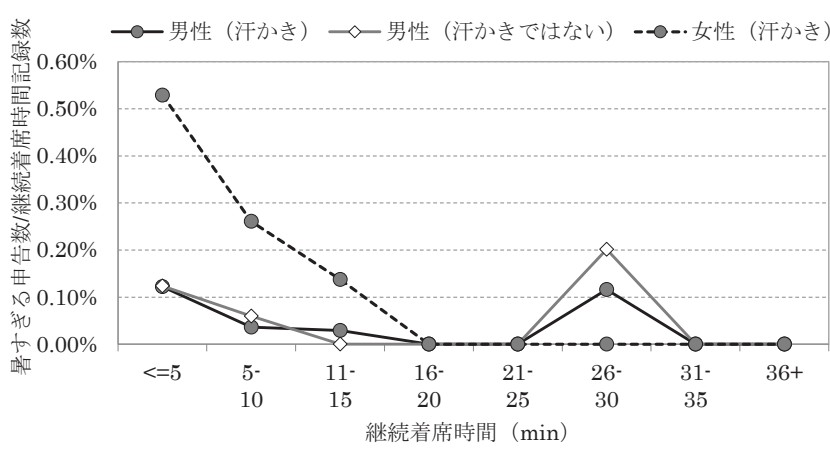

図 20 汗かき体質と「暑すぎる」申告

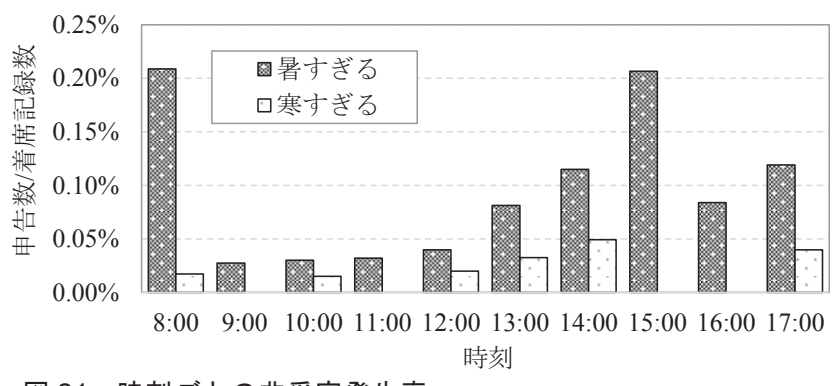

図 21 時刻ごとの非受容発生率

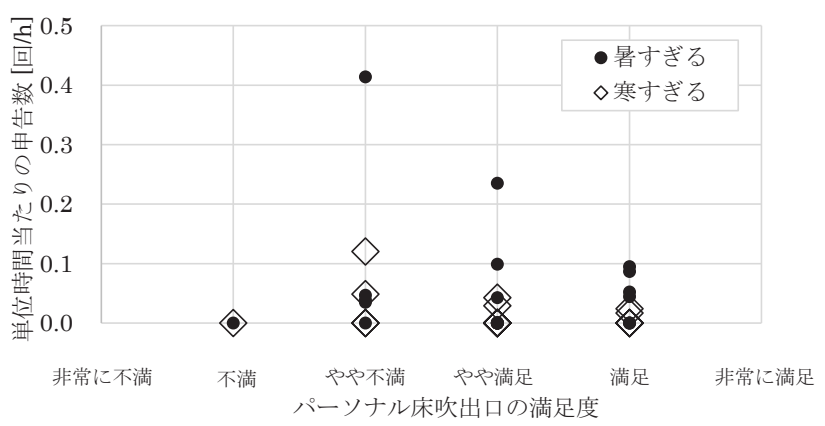

図 22 パーソナル床吹出ロの満足度と非受容申告 
面から検討したのと同時に, オストラコンによる執務者の非受容発 生時の詳細な状況を捉えた結果を以下に示す。

1）本建物の平均放射温度は空気温度と比べて低い值を示した。 また，上下温度分布が非常に小さい室内環境であり時間的な 変動も少なく, 放射空調の特徴である室内全体にムラのない 環境が実現できていることを確認した。

2）放射空調下の気流環境は非常に静穏であるが，インテリアゾ ーンで平均 $0.07 \mathrm{~m} / \mathrm{s}$ の自然対流の存在を確認した。

3）執務者の室内温熱環境に対する印象は，約 8 割の回答が「や や暖かい」から「やや涼しい」の範囲であり, 気流感と総合的 な室内温熱環境の印象も非常に良好であることから，気流感 による不快が少ない均一な環境が実現できていると判断でき る。

4）室内温熱環境の快適性の印象とオストラコンによる非受容申 告数には負の相関が見られた一方で, 執務者は一般的に受容 される温熱環境であっても非受容申告を行うことを確認した。 また,「暑すぎる」申告は着席直後に頻発し，また「寒すぎる」 申告は長時間の着席時に発生していたことから, 熱的不満の 背景には室内温熱環境の快適性の問題と, 執務者の熱的な履 歴の 2 種類のファクターが考えられる。

\section{参考文献}

1）小沢朝江，水沼淑子：日本居住史，吉川弘文館，2006

2）黒川正流監訳 : 仕事の場の心理学ーオフィスと工場の環境デザインと行 動科学, 西村書店, 1992

3) Fanger, P.O: Thermal Comfort, Danish Technical Press, 1970

4) Nicol, J. F. and, Humphreys, M. A.: Thermal comfort as part of a selfregulating system, Building Research and Practice (J. CIB), 6(3), pp.191-197, 1973

5) Humphreys, M. A. and Nicol, J. F.: Understanding the adaptive approach to thermal comfort, ASHRAE Transactions, 104(1b), pp.991-1004, 1998
6） 中野淳太，田辺新一：半屋外環境の熱的快適性に関する考察一温熱環境 適応研究の日本における温熱環境計画一の応用とその課題一, 日本建築 学会環境系論文集，701,pp.597-606, 2014.7

7) Humphreys, M. A.: Thermal comfort temperature and the habits of hobbits, Standards for thermal comfort: Indoor air temperatures for the $21^{\text {st }}$ century, E\&FN Spon, London, pp.3-13, 1995

8) 村上周三 : 知的生産性生活の展望, 特集ワークプレイスプロダクティビ ティ, 空気調和・衛生工学, Vol. 81(1), pp.3-8, 2007.1

9）田辺新一, 西原直枝: 室内温熱環境における知的生産性評価, 特集ワ一 クプレイスプロダクティビティ, 空気調和・衛生工学, Vol. 81(1), pp.9$14,2007.1$

10）興水ヒカル，栃原裕，東賢一，池田耕一：夏期における「クールビズ」 実施オフィスの温熱環境およびその勤務者評価に関する調査, 第 30 回 人間一生活環境系シンポジウム報告書, pp.283-286, 2006.12

11）大熊涼子, 石野久彌, 中山哲士 : 夏期のオフィスにおける $28^{\circ} \mathrm{C}$ 空調の熱 的快適性に関する研究，日本建築学会環境系論文集，618, pp.31-36, 2007.8

12）羽田正沖, 西原直枝, 中村俊輔, 内田智志, 田辺新一 : 夏季室温緩和設 定オフィスにおける温熱環境実測および執務者アンケート調査による 知的生産性に関寸る評価, 日本建築学会環境系論文集, 637, pp.389-396, 2009.3

13）村上昌史，原田昌幸，久野覚，寺野真明：居住者の温熱要望申告を利用 した空調制御方式に関する研究, 日本建築学会環境系論文集, 626, pp.535-542, 2008.4

14）荻野司, 酒井浩介, 志田智, 須永修通 : 在室者の調整行動を利用した省 エネ空調制御システムに関する研究，日本建築学会環境系論文集，704， pp.871-881, 2014.10

15）金子弘幸，大佛俊泰：レーザーセンサによる行動モニタリングデータを 用いた時空間活動パターンの抽出, 日本建築学会環境系論文集, 712 , pp.559-566, 2015.6

16) T. Nobe, S. Tanabe, S. Lee, Y. Tomioka: Investigation of Seat Occupancy Rate in Office, ROOMVENT 2002 Proceedings, September 2002, pp.289-292, Copenhagen, Denmark

17）花田嘉代子：着衣量, 温冷感シンポジウム「温熱環境測定法」, 空気調 和・衛生工学会空気調和設備委員会・温冷感小委員会, 空気調和・衛生 工学会, 1992 


\title{
INVESTIGATION OF INDOOR THERMAL ENVIRONMENT AND CONSIDERATION ON THERMAL ENVIRONMENTAL ACCEPTABILITY AT OFFICE S
}

\author{
Masanari UKAI*, Mitsuhiro TAKAHASHI**, Koji MURAKAMI**, \\ Saya AMEMIYA*** and Tatsuo NOBE **** \\ * Grad. Stud., Dept. of Architecture, Faculty of Engineering, Kogakuin University \\ JSPS Research Fellow \\ * Shimizu Corporation \\ *** Shimizu Corporation, Dr.Eng. \\ **** Prof., Dept. of Architecture, Faculty of Architecture, Kogakuin University, Dr.Eng.
}

This paper reports the summertime measurement results of the indoor thermal environment at the head office of $\mathrm{S}$ Company. On the subject of air conditioning system, the perimeter zone supplies cold water to a perimeter chilled beam and it processes the perimeter cooling load. The interior zone adopts a task and ambient air conditioning system. Ambient air conditioning supplies cold water to an interior radiation ceiling panel and processes the internal heat generated by human bodies, lighting, OA equipment, and so on. In addition, the air carried out during latent heat processing with the desiccant air conditioning system is supplied from the personal floor outlet installed under the desk. The current from a personal floor air outlet provides air conditioning and it can be adjusted to an individual's preference.

This study aims to evaluate the thermal comfort of an indoor environment in office from physical quantity and psychological state. Moreover, this study aims to assess the thermal conditions of an indoor environment deemed unacceptable by workers that it is impossibility to evaluate from conventional method. For this purpose, the acceptability voting device "Ostracon" was developed, which can record the physical environment when workers express a complaint. Workers can push a button on Ostracon to vote when they feel that the thermal environment is unacceptable. In this study, Ostracon was used to measure whether 25 workers felt that the thermal environment was acceptable in the office $\mathrm{S}$ during the summer.

The results showed that the mean radiant temperature was lower than room temperature. Moreover, up-and-down temperature distribution was very small. In addition, the temperature difference to every time is smaller during the up-and-down temperature distribution. Distribution stability throughout the day should be confirmed. For this reason, it was determined that the radiation ceiling panel was effective. Regarding questionnaire about satisfaction with the room environment, the many of respondents said they were "comfort" overall. The result showed a very high level of satisfaction. Regarding the survey of Ostracon, subjects expressed that the environment was unacceptable even when the temperature and humidity were within an acceptable range. Therefore, the authors consider that thermal environmental acceptability is not determined simply by temperature and humidity. However, it was observed that the workers' complaints were often expressed moments after returning from tasks performed outside the office, suggesting that their complaints were influenced by factors other than the office environment, such as changes in metabolic rate and the individual's thermal history. 